\title{
Parent's Perception on Disaster Education for Early Childhood at Disaster-Prone Areas
}

\author{
Lulu Diyanti Putri ${ }^{1, *}$, Heny Djoehaeni ${ }^{2}$, Rudiyanto ${ }^{3}$ \\ ${ }^{1,2,3}$ Pendidikan Indonesia University \\ ${ }^{*}$ Corresponding author. Email: luludiyantiputri@upi.edu
}

\begin{abstract}
The background of this research is due to the many cases of natural disasters in Indonesia. In early childhood, both consciously and unconsciously, they often become victims of natural disasters both physically and psychologically. This phenomenon has become commonplace in today's society. Many parents still do not understand how to teach education for early childhood, so children are not taught optimally and based solely on the experience of parents. The purpose of this research is to find out the perception of parents towards disaster education in early childhood in disaster-prone areas, both in the knowledge and understanding of parents. This research used a qualitative method with phenomenological approach. The findings showed that parents' understanding is good enough in terms of disaster education, this is seen when parents teach disaster education at home, but disaster education that parents provide is based only on the experience of parents. Recommendation of this research is aimed at parents to be active in preparing themselves with adequate science so that children get the right disaster education and in accordance with their growth and for further researchers to be able to research further by uncovering the same problems but with different subjects and variables. So that in the future this research can be developed and its benefits are wider for many people.
\end{abstract}

Keywords: Early childhood, parents, disaster education.

\section{INTRODUCTION}

Indonesia is bypassed by the Indo-Australian plate on the south, the Pacific from the east and Eurasia from the north, thus, Indonesia is in the area of the ring of fire. Consequently, Indonesia has many active volcanoes and also high potential for natural disasters, such as volcanic eruptions, earthquakes, tsunamis, floods and landslides [1]. The National Disaster Management Agency (BNPB) noted that during 2019 to December 23, there have been 3,721 natural disaster events in Indonesia. BNPB predicts the number of disasters will continue to increase [2].

Indonesia's proneness from natural disasters shows the importance of disaster education from an early age. This is because in every natural disaster, children are often the most affected community group. This group, if not physical victims, is usually the most psychologically affected group [3]. Because of that, there needs to be a briefing on efforts to reduce the impact of disasters, namely disaster education [4].

Disaster education is very important for early childhood in order to raise awareness of disaster preparedness. So that this can be embedded in children how to maintain safety, at least for themselves from the impact of disasters [5], [6]. According to the Guidelines for Disaster Education in PAUD Unit this guideline describes disaster education materials for early childhood consisting of three stages. That is pre-disaster, during disasters, and post-disasters [4]. The three stages are very important and need to be socialized and implemented in early childhood disaster education. This is explained in order to form children who are agile and responsive in the face of disasters.

Based on research conducted by Ningtyas she researched that disaster education in early childhood can be integrated into learning in schools by means of circuit games [7]. Other than that, Ningtyas and Risina have also researched in Pertiwi Kindergarten group B at Samiran in Boyolali regency with video media about disaster education can also improve children's self-awareness ability in disaster response [8].

But, in the two researchers that have been done, it is not explained how the role of families in teaching disaster education in early childhood. Yanuarto stated that the family has an important role in providing socialization to each member [9]. Socialization can be given in the form of introduction of potential disasters, forms of disasters, how to save yourself in disaster conditions, how to make psychological comfort, how to store disaster supplies kit, how to make emergency tents, and how to preserve the environment as an effort to reduce the risk of disasters due to human behaviour [9]. 
However, Siregar said that empirically, so far parents or prospective parents in general have not been prepared to become real parents, in the sense of parents who are able to provide educational and parenting services that are in accordance with their growth and development [10]. In general, they are not ready to educate and nurture their children. Siregar also said that the average of them (parents) do not have enough knowledge, insight, and skills about early childhood education, especially disaster education [10]. As a result it is predictable that in providing educational and nurturing stimulation, they tend to use natural perceptions (just the way they know) like a running water [10].

Walgito stated there are two factors that influence the occurrence of perception, that is the individual state as a preceptor, which is a factor from within the individual itself such as thoughts, feelings, points of view, past experiences, comprehension, level of intelligence, expectations and as well as guesses of preceptors and perceived object states that are the characteristics displayed by objects [11].

Various factors that influence the occurrence of perceptions in parents cause a variety of perceptions about children's education [10]. Because of that, researchers are interested in studying more deeply about parents' perceptions about disaster education in early childhood. Based on the problems that have been conveyed, the problem formulation of this research is how parents perceive disaster education in early childhood?

\section{METHOD}

The research method used is qualitative research method. Qualitative research is a research used to understand the research respondents with an in-depth and interpretive nature which means to find and discover the meaning [12]. Based on this, this research was carried out with the aim of gaining a broader and deeper understanding of disaster education in early childhood that develops in society.

The design of the research that will be done in this research. That is phenomenological research. This phenomenological research tries to explain or reveal the meaning of concepts or phenomena of experience based on consciousness that occurs in some individuals [13].

Phenomenological approach was chosen because it is in accordance with the purpose of research, namely to examine in detail about social phenomena of disaster education phenomenon in early childhood that occur in real and the way it is. Based on the statement stated by Moleong in phenomenological viewpoint, researchers seek to understand the meaning of events and their relation to ordinary people in certain situations [13]. The use of phenomenological methods is intended to be able to describe the symptoms or phenomena that appear as they are from the research object.

Respondents in this research were four parents who have children at an early age. This research place was conducted at Dayeuhkolot Road, Kaum Village, Dayeuhkolot Sub-district Bandung. Researchers chose this place because Kaum Village in Dayeuhkolot Subdistrict is one of the areas that are severely affected when affected by floods every year.

Instruments in this research used human instruments and the data collection techniques were semi-structured interview techniques. Qualitative data analysis in this research is using Interpretative Phenomenological Analysis (IPA) method and equipped with reflectivity from researchers.

\section{RESULT AND DISCUSSION}

\subsection{Children's education is the most important}

Based on this research, it was found that parents have a viewpoint about education for early childhood is important as a basis for children's provision when they grow up and can form good character for children. Researchers see the rise of parental concern in early childhood education. Other than that, the four respondents have also sent their children to PAUD, which also proves that parents care about the importance of education from an early age.

From the respondent's statement, there are two points that researchers can conclude. The first is that education is the basis of children's provision when they grow up and the second is that education can create good character. Education as the basis of children's provision to adulthood means that parents have aspirations so that their children can succeed in their adulthood by providing adequate education for their children from an early age. Because early childhood is at the golden age stage where children should be given the best stimulation to help their future life [9]. Meanwhile, character education can be the basis for the formation of human personality as a whole. That is for the formation of character, noble character, intelligent, cheerful, skill, subject to the God Almighty [14], [15]

From the two points that exist, researchers can conclude that the education of children for parents is the main thing, because education can be a provision when the child becomes an adult later and can form good character in early childhood. It can be formed by parents by means of habituation and positive support from both parents. 


\subsection{Parent's viewpoint on the notion of disaster education in early childhood}

The four respondents in this study have almost the same viewpoint regarding the meaning of disaster education for early childhood. This is expressed by the subject or parents in the following interview. Disaster education is education about various types of disasters, education to overcome natural disasters and education in dealing with disasters.

Based on the researcher, four respondents conceptually had sufficient understanding of disaster education. However, theoretically the four respondents still do not understand the meaning of disaster education itself. So this can result in less anticipatory attitudes of parents towards preventive efforts to protect children in the context of disaster education. Therefore, education is needed for parents in increasing their awareness and understanding of the importance regarding disaster education, especially for early childhood.

Parents' depth understanding regarding the meaning of disaster education for early childhood is very important, because parents have many roles in preparing, predicting disaster threats, and reducing disaster risk in the family environment [16].

\subsection{Parent's viewpoint on the urgency of disaster education in early childhood.}

In this study, all four respondents have the viewpoint that disaster education for early childhood is important. Parents see that this is important because so that children have knowledge about natural disasters, children can anticipate natural disasters, children can know what they should do and what they should not do, and children can know how to deal with disasters, how to prevent them and disaster rescue.

Based on the findings of the respondents' statements, parents have begun to introduce their children little by little about disaster education from an early age. However, it has not been seen that there has been any parents' efforts to deepen their knowledge of disaster education. This is in accordance with the statements of the four respondents that they have never sought more information about disaster education for early childhood from print media, the internet or following training. According to the researchers, parents are expected to take the time and be active in seeking information in various media such as radio, newspapers, and the internet and join training related to educational information for early childhood. In order for disaster education in the family to be carried out optimally, parents as agents of socialization must have adequate mastery of disaster education [5].

\subsection{Parent's viewpoint in teaching skills and knowledge about steps that must be taken before a disaster occurs}

The viewpoint of parents in this study regarding knowledge and skills, should be taught to early childhood before a disaster occurs, namely introducing the causes of flooding, urging not littering and loving the environment, preparing yourself, knowing what items should be saved such as books, clothes, food, etc. And start learning to pack things and put them in bags, know the signs of a flood, empty the lower drawers, know various warnings of the arrival of disasters (sirens sound or announcements from the RT or mosque chairman).

Based on the viewpoint of the four respondents, the understanding of parents in teaching knowledge, and early childhood preparation skills before the disaster in this study is quite good. However, it would be better if the preparations could be more adjusted to disaster guidelines, so that parents can reduce the risk of disasters in their families.

Based on the guidelines for family disaster preparedness services [17]:

1. Provides understanding to children about conditions that may occur due to flood disasters, for example collapsed houses, drifting equipment, items swept away by floods.

2. Informing about the risks resulting from flooding, for example resulting in injury, death and loss of property.

3. It is better if children are given an explanation of what to do in case of flooding, such as not approaching the flood, not crossing the flood, immediately looking for a higher area.

4. Prepare/inform self-rescue efforts, for example climbing to a higher place, how to use a buoy or other means.

5. Inform the child about the items that must be prioritized for securing, for example children's books, school uniforms or other important documents.

6. Develop preparedness to deal with flooding specifically, according to the cases that are often faced (swimming).

7. Teach children to ask for help from people around, neighbors or the authorities.

8. Introduce children to early information systems. Especially for people who live in watershed areas because they are very prone to flooding, so that they should evacuate themselves early to prevent casualties and provide a special buoy for children. 
9. Teach children self-rescue steps, for example how to use a buoy, coping techniques (for example how to hold a rope) and swimming.

10. Inform children of upland areas that can be used at any time in the event of a flood.

11. Plan the necessary needs with the child during evacuation or stay at home.

12. Socialize to children the storage place for their needs if they have to leave the house.

13. Discuss what to do during the flood before the appointed time, so that you can reduce fear and let everyone figure out the answers for themselves.

Based on this, according to the researcher, parents should find out about actions and knowledge before natural disasters occur, so that families can live more calmly and in harmony with the disasters that occur.

\subsection{Parent's viewpoint in teaching knowledge and skills regarding steps to take when a disaster occurs}

The viewpoint of parents in this study regarding the knowledge and skills that should be taught to early childhood, when a flood occurs is to inform the children about the place of refuge, learn to swim, forbid children to play when the flood is too far away, forbid children to play in flood water for too long, beware of sharp objects or dangerous beasts, learn to use buoys or blowing their own buoys, dare to ask for help (say help) to others, forbid children to eat food carelessly.

Based on the viewpoint of parents in this study, parents are good enough in teaching skills and knowledge about steps to take when a disaster occurs. However, parents should also adjust to the applicable guidelines for disasters for early childhood.

From the existing opinion, it can be connected with the statement in the pocket book of responsive agility to face disasters issued by the National Disaster Management Agency that is [18]:

- $\quad$ Teach children to avoid walking near waterways to avoid being swept away by flood currents.

- Teach children to remind their parents to turn off the electricity in the house

- Invite children to evacuate to safe areas or flood posts as early as possible, when puddles are still possible to be passed.

- Invite the children to secure valuable items to higher places.

- If the water continues to rise, teach children to contact local residents or agencies related to disaster management, such as the village head, village head, or sub-district head.

\subsection{Parent's viewpoint in teaching knowledge and skills regarding steps to be taken after a disaster occured}

The viewpoint of parents in teaching knowledge and skills about the steps that must be done after a flood is to clean up the house again, introduce first aid, children learn to medicate them self, be careful with dangerous animals, clean items that are affected by flooding, clean stagnant water, and forbid children not to eat food that has been flooded.

From the above statement, the researcher concludes that the viewpoint of parents in teaching knowledge and skills regarding the steps that must be taken after a disaster occurs are still incomplete if they are linked to disaster guidelines. So that parents should learn more and apply the steps that must be taken after a flood disaster and adjust to disaster guidelines in order to avoid children and families from various threats after a disaster such as the emergence of various diseases.

Based on Rampangilei, there are eleven steps for parents to teach disaster preparedness for families after a flood, including [17];

- Teach children to avoid flood water because of the possibility of contamination with hazardous substances and the threat of electrocution.

- Teach children to be aware of electrical installations.

- Teach children to avoid moving water.

- Teach children to avoid areas where the water has just receded as the roads can be damaged and collapsed.

- Teach children to return home according to orders from the authorities.

- Teach children to stay outside of buildings / houses that are still surrounded by water.

- Teach children to always be careful when entering buildings because of the threat of damage that is not visible, such as the foundation of the house.

- Teach children to always wash their hands using soap and clean water when exposed to flood water.

- Teach children to throw away and not eat food contaminated with flood water.

Encourage the child to clean the living area and home environment from the remaining dirt after the flood. Based on this statement, it is important for parents to 
know the right steps when a natural disaster occurs, so that they are better prepared and responsive to natural disasters. Not only parents, children who have been provided with disaster education can also remind their parents about important things.

Encourage children to eradicate mosquito nests / Mosquito Nest Eradication (PSN).

Based on this statement, it is very important for parents to explore more information and apply steps that should be taught to early childhood after a disaster occurs, in order to avoid various diseases due to receding floods.

\subsection{Parent's viewpoint on learning methods for early childhood regarding disaster education}

The viewpoint of the four respondents regarding learning methods for early childhood regarding disaster education are sufficient, by using the method of conversing (chatting), question and answer (discussing), telling stories and reading magazines or watching TV.

Based on the viewpoint of the four respondents, parents' knowledge of learning methods is still lacking. This results in less variation in the learning methods used by parents. With the variety of methods used, it is hoped that the creation of learning that is more effective, fun and easy to understand by children.

According to the Guidelines for Disaster Education in the ECE Unit [4], there are learning methods that parents can use in learning disaster education for early childhood, including;

\section{- Chat Method}

With the conversation method, parents can invite children to express their feelings according to their level of development related to disasters.

\section{- Question and answer method}

With the question and answer method, parents can explore the child's level of understanding.

\section{- $\quad$ Storytelling Method}

With the storytelling method, parents can invite children to imagine the characters, setting, language style, and storyline. This is expected to make it easier for children to understand the anticipation of disasters, disaster management efforts, and other matters related to disasters.

\section{- $\quad$ Field Trip Method}

The method of field trip will help children understand real life in their surroundings, for example certain areas affected by a disaster.

\section{- Demonstration Method}

In the demonstration method, parents need to correct the explanation given by practicing directly or by using the media to further clarify a concept to be taught.

\section{- Sociodrama Method}

With the sociodrama method, parents can invite children to play the events seen in their daily lives. Other than that, parents can also include the educational value of disasters in the drama.

\section{- $\quad$ Role Playing Methods}

Role playing method Different from socio-drama, in the method of role playing will be done by the child to play a character of their choice in the form of macro and micro Role

\section{- Experimental Method}

Experimental method is a learning method characterized by the activities of parents and children trying to do something, observe and report the experiment process. For example, when conducting experiments on making flood containment using the media of parent's designs which then continued with the activities of the child.

\section{- $\quad$ Project Methods}

In the context of disaster education, this method can be done by looking at the impacts and consequences caused by a disaster with the assistance of parents. After making observations, children can discuss and make activities related to how to deal with disasters or overcome disasters.

From the learning methods described above, researchers can conclude that there are many variations of learning methods that can be used by parents during the teaching and learning process, especially in disaster education in early childhood. Because of that, parents should be more active in trying new and varied methods so as not to be monotonous and boring for the child.

\subsection{Parent's viewpoint on attitudes that should be taught to early childhood in the face of natural disasters}

Parent's viewpoint in teaching attitudes to dealing with disasters in early childhood are quite good. Such as teaching to always be patient, grateful to the events that occur, one of which is the disaster that has ended. Parents in this research also teach to be diligent in re-tidying the equipment and tools in the house, both privately owned and family-owned and always love and maintain the environment, so that the environment remains clean, safe, comfortable and far from natural disasters. Researchers found that it was strong enough for parents to instill a religious attitude to the child. 
Children also need to be introduced to the attitude of loving nature, in order to grow awareness of keeping and preserving nature as friends [19]. By being friendly to nature, nature will be friendly to us. Nurfadhilah and Ramadhani, A, N also stated that the need to be taught from an early age attitude of responsibility towards themselves and respect as well as care for the surrounding environment [20].

However, there is still something parents need to know in teaching attitudes to dealing with natural disasters. As hung, D stated in his writing mentions there are four attitudes applied by Japanese society from an early age in the face of disasters, that is [21];

\section{- Discipline}

Japan has started teaching its children to stay in order. It's already started from simple things like queuing up. So there is almost no commotion when the distribution of food in the refugee shelter, this is very helpful to accelerate everything and increase solidarity for each refugee.

\section{- Unselfish}

Despite the disaster, this is not an excuse for them to fight each other. They even work hand in hand to help others who are more in need. Like giving more food to their starving friends, queuing, and other proud acts.

\section{- Act efficiently and agile}

When disaster happens, Japanese people will no longer be confused with what they should do because they already know. They will bring valuables as efficiently and as quickly as possible to the evacuation site. As a result, the death toll can also be minimized and the evacuation can be done properly.

\section{- Always on standby}

The secret of Japanese community in dealing with disasters is that they are always ready for disasters. They have received disaster management training since childhood and continue to be done even though they are adults. This helps them know the necessary actions when disaster occurs. As a result, panic did not occur and the evacuation process became smoother.

Researchers can conclude that if parents have taught a good attitude to their children from an early age in the face of natural disasters, it can reduce the threat of children becoming victims of natural disasters themselves, especially reducing the sense of trauma in children.

\section{CONCLUSION}

Based on the results of research obtained by researchers, it can be concluded that the viewpoint of parents on disaster education in early childhood in disaster-prone areas is quite good as a concept but theoretically still incomplete if juxtaposed with the applicable disaster guidelines. Parents already consider it important to have disaster education in early childhood.

In preparation before the disaster, parents have had a sufficient viewpoint, that is by teaching early childhood to do not litter and love the environment, prepare themselves, know what items to save such as books, clothes, food, etc. and start learning to pack their own belongings and put in bags, know the signs of the coming flood, empty the bottom drawers, know the various warnings of the arrival of disasters (sirens or announcements from the neighbourhood leader or mosques).

At the time of the disaster, parents have had enough viewpoint by teaching to introduce shelter to children, learning to swim, prohibiting children from playing when the flood is too far away, prohibiting children from playing in floodwaters for too long, being careful of pointy objects or dangerous animals, learning to use buoys or blowing their own buoys, daring to ask for help (say help) to others, prohibiting children from eating food carelessly.

In the aftermath scene of the disaster, parents have had enough viewpoint by re-cleaning their homes, introducing first aid, children learning to treat themselves, being careful with dangerous animals, cleaning up flooded items, cleaning up flooded water and prohibiting children from eating food that has been affected by floods.

Parents' viewpoint of the learning methods used when introducing disaster education is simply by talking, questioning, telling stories and reading magazines or watching TV.

Parents' viewpoint in teaching attitudes for dealing with disasters in early childhood is quite good. Such as teaching to always be patient, grateful and to the events that occur, one of which is the disaster that has ended. Parents in this research also teach to be diligent in retidying the equipment and tools in the house, both privately owned and family-owned and always love and maintain the environment, so that the environment remains clean, safe, comfortable and far from natural disasters.

From the results of the research that has been done, this stated that parents are good enough in teaching disaster education in early childhood. But parents already feel enough in teaching disaster education based only on their experience. So, it can cause a lack of preventive attitude of parents on efforts in child care, which is in the context of disaster education. Because of that, education is very necessary for parents in raising their awareness and understanding of the importance of disaster education, especially for early childhood. 


\section{REFERENCES}

[1] Warsono. Pembelajaran aktif teori dan asesmen. Bandung: PT Remaja Rosdakarya; 2012.

[2] Badan Nasional Penanganan Bencana. Buku saku tanggap tangkas tangguh menghadapi bencana. Jakarta: BNPB; 2019. Available from: https://bnpb.go.id.

[3] Sudarma M. Sosiologi dan kesehatan. Jakarta: Salemba Medika; 2018.

[4] Hasbi M. Pedoman pendidikan kebencanaan di satuan PAUD. Jakarta: Direktorat Jenderal Pendidikan Anak Usia Dini dan Pendidikan Masyarakat Kementerian Pendidikan dan Kebudayaan; 2010.

[5] Desfandi M. Urgensi kurikulum pendidikan kebencanaan berbasis kearifan lokal di Indonesia. SOSIO-DIDAKTIKA: Social Science Education Journal. 2014;1(2):191-8. Available from: http://103.229.202.71/index.php/SOSIO-

FITK/article/download/1261/1127

[6] Oebadillah S. Mitigasi bencana anak PAUD investasi masa depan. Media Indonesia. 2019 January 27. Available from: https://mediaindonesia.com/humaniora/213230/miti gasi-bencana-anak-paud-investasi-masa-depan.

[7] Ningtyas DP, Risina DF. Pengembangan permainan sirkuit mitigasi bencana gempa bumi untuk meningkatkan self-awareness anak usia dini. Jurnal Caksana: Pendidikan Anak Usia Dini. 2018;1(2):1$16 . \quad$ Available from: https://doi.org/10.31326/jcpaud.v1i02.198.

[8] Ningtyas DP, Risina DF. Peningkatan selfawareness anak usia dini melalui media video mitigasi bencana gunung meletus. Al-Athfal: Jurnal Pendidikan Anak. 2018;4(2):113-24.

[9] Yanuarto T. Buku saku tanggap tangkas tangguh menghadapi bencana. Jakarta Timur: Pusat Data Informasi dan Humas BNPB; 2018.

[10] Siregar NS. Persepsi orang tua terhadap pentingnya pendidikan bagi anak. JPPUMA: Jurnal Ilmu Pemerintahan dan Sosial Politik UMA (Journal of Governance and Political Social UMA). 2013;1(1):11-27.

[11] Walgito B. Pengantar psikologi umum. Yogyakarta: CV Andi Offset; 2014.

[12]Rahmat P.S. Penelitian kualitatif. Jurnal Equilibrium. 2009;5(9):1-8.

[13] Moelong L. Metodologi penelitian kualitatif. Bandung: PT Remaja; 2010.

[14]Fakhruddin AU. Pendidikan anak usia dini sebagai alas pendidikan. INSANIA: Jurnal Pemikiran Alternatif Kependidikan. 2009;14(2):231-41.
Available from: http://www.ejournal. iainpurwokerto.ac.id/index.php/insania/article/dow nload/328/293.

[15] Rustini T. Pendidikan karakter anak usia dini. Cakrawala Dini: Jurnal Pendidikan Anak Usia Dini. 2012;3(1):1-9. DOI:10.17509/cd.v3i1.10321.

[16] Setyowati DL. Pendidikan kebencanaan. Semarang: Universitas Negeri Semarang; 2019. Available from: http://lp3.unnes.ac.id.

[17] Rampangilei W. Panduan kesiapsiagaan bencana untuk keluarga [internet]. Jakarta: BNPB; 2018. Available from: https://siaga.bnpb.go.id.

[18] Utomo H, Buana FC. Pedoman standar layanan kesiapan keluarga. Jakarta: Kementerian Pemberdayaan Perempuan dan Perlindungan Anak; 2017.

[19] Kelana NS. Demi keselamatan, Yuk ajari anak tanggap bencana [Internet]. Siedoo. 2020 January 7. Available at: https://siedoo.com.

[20] Ramadhani AN, Nurfadilah N. Kesiapsiagaan lembaga PAUD di Bogor dalam menghadapi bencana longsor. In Seminar Nasional dan Call for Paper Membangun Sinergitas Keluarga dan Sekolah Menuju PAUD Berkualitas. 2018:172-179.

[21]Hung D. Ketika bencana alam, 5 sikap orang Jepang ini perlu kamu tiru [Internet]. IDN Times. 2018 September 18. Available from: https://www. idntimes.com. 